\title{
Effect of Three Post-Emergence Herbicides on Coffee Growth and Weed Control ${ }^{1}$
}

\author{
Elvin G. Boneta García ${ }^{2}$ \\ ABSTRACT
}

Glyphosate, paraquat and dalapon were evaluated as post-emergence herbicides for weed control in young sun-grown coffee trees. The experiment was conducted in lat. $18^{\circ} \mathrm{N}$. and long. $66^{\circ} 48^{\prime} \mathrm{W}$., and at an elevation of 588 $\mathrm{m}$. Glyphosate killed the weeds more effectively than paraquat and dalapon. Excellent weed control was observed at 4.70, 7.05 , and $9.401 /$ ha, and very good control when applied at $2.35 \mathrm{I} / \mathrm{ha}$. Coffee growth was temporarily retarded only when the glyphosate solution drifted to the tree. Dalapon did not provide control against broadleaf weeds.

\section{INTRODUCTION}

Coffee production in Puerto Rico for 1978-79 was 9,525,600 kg, with a farm value of $\$ 37.4$ million, that is, $7 \%$ of the total agricultural gross income. This production represents a decrease of $3,624,400 \mathrm{~kg}(2.3 \%)$ as compared to that of $1977-78$.

The number of new sun-grown coffee plantings is increasing significantly (9), a tendency which is expected to continue, since the present agricultural program is directed toward this goal. At present, the establishment of these coffee groves requires a high initial investment, and new technology must be applied in order to attain a production of 16.95 to $22.60 \mathrm{~kg} / \mathrm{ha} 3$ years after planting.

The climate of Puerto Rico, characterized by high precipitation and warm temperature throughout the year, offers ideal conditions for weed growth. Weeds constitute a critical problem, especially in young sungrown coffee trees. The use of $1.22 \times 3.05 \mathrm{~m}$ or similar spacings provides ample space for the abundant weed growth. Handweeding is a very expensive operation. Post-emergence herbicides should be used at the correct rates and frequencies in order to lower the operation costs. Competition for nutrients and soil moisture between weeds and coffee seedlings (8) is one of the important factors limiting growth and yield of coffee farms. In addition, weed infested groves are difficult to fertilize, harvest, and control efficiently against insects or diseases.

Weeds have to be eliminated by hand frequently during the rainy season. This weeding, besides being an ineffective method of control (1), is a very costly operation. Frequently, labor is scarce and undependable.

\footnotetext{
${ }^{1}$ Manuscript submitted to Editorial Board June 9, 1982.

${ }^{2}$ Associate Horticulturist, Adjuntas Substation, Agricultural Experiment Station, Mayagüez Campus, University of Puerto Rico, Río Piedras, P. R.
} 
On the other hand, herbicides have proved to be an effective and economical control method, provided the product is effective for the weed species prevalent in the area. With this fact in mind, an experiment was designed to test the effectiveness of glyphosate ${ }^{3}$ ([N-(phosphonomethyl) glycine]), paraquat (1,1-dimethyl-4,4-bipiridinium dichloride), and dalapon (2,2-dichloropropionic acid).

For the coffee grove, the most desirable herbicides are those of contact or systemic action with good weed control under a wide range of climatic conditions $(4,6,10)$. Because these herbicides kill the weeds, the user avoids damaging coffee trees by directing the spray to the weeds $(8,3)$. Burril et al. (2) indicated the desirability of combining two herbicides to increase the control of grasses and broadleaf weeds.

Dalapon, paraquat, mixtures of diuron with dalapon or paraquat, and glyphosate have been evaluated for weed control at the Adjuntas Substation. Boneta-Garcia (1) pointed out that paraquat applied at 1- or 2month intervals provided excellent weed control. Dalapon at 5.65 and $11.3 \mathrm{~kg} /$ ha was equally effective on grasses, but ineffective on broadleaf weeds. The addition of diuron to dalapon or paraquat solutions to increase effectiveness of control was questionable because of its toxicity to the coffee trees. Glyphosate (1.9 1/ha) provided good weed control without producing detrimental effects on tree growth and yield. Páez (7) in 1973 showed the effectiveness of dalapon for Panicum maximum control. Liu (5) pointed out that despite the crop injury encountered as a consequence of drift effect, weed control achieved with post-emergence herbicides glyphosate and paraquat in plantains appeared highly promising.

\section{MATERIALS AND METHODS}

A field experiment was conducted at the Adjuntas Substation, located in the Central Humid Region of Puerto Rico, from August 1978 to February 1980 . The experiment was planted at lat. $18^{\circ} 11^{\prime}$ N., long. $66^{\circ} 48^{\prime}$ W., and at an elevation of $588 \mathrm{~m}$. The soil is an Orthoxic Trophohumults, clayey, oxidic, isohyperthermic. The total rainfall recorded during the experiment was $2,865 \mathrm{~mm}$, ranging from 427 in August 1979 to 134 in January 1980.

Seven treatments were replicated six times in a partially-balanced. incomplete paired-plot design. Six-month-old seedlings of the Bourbon variety were planted $1.22 \mathrm{~m} \times 3.05 \mathrm{~m}$ apart August 15, 1978. Each experimental plot consisted of eight trees.

\footnotetext{
${ }^{3}$ Trade names in this publication are used only to provide specific information. Mention of a trade name does not constitute a warranty of equipment or materials by the Agricultural Experiment Station of the University of Puerto Rico, nor is this mention a statement of preference over other equipment or materials.
} 
TABLE 1.-Percentage weed control on a young coffee grove as affected by the application of post-emergence herbicides

\begin{tabular}{|c|c|c|c|c|c|c|c|c|c|c|}
\hline \multirow{2}{*}{ Herbicide } & \multicolumn{7}{|c|}{1979} & \multicolumn{3}{|c|}{1980} \\
\hline & April 17 & May 21 & June 19 & Aug. 7 & Oct. 5 & Nov. 15 & Dec. 5 & Jan. 14 & Feb. 12 & March 12 \\
\hline Glyphosate (2.35 l/ha) & $14.17 \mathrm{~cd}^{1}$ & $23.33 \mathrm{~b}$ & $65.20 \mathrm{~b}$ & $81.67 \mathrm{a}$ & $86.17 \mathrm{a}$ & $12.50 \mathrm{ab}$ & $73.83 \mathrm{~b}$ & $92.83 \mathrm{a}$ & $74.17 \mathrm{a}$ & $97.67 \mathrm{a}$ \\
\hline Glyphosate (4.70 l/ha) & $46.67 \mathrm{~b}$ & $79.67 \mathrm{a}$ & $96.67 \mathrm{ab}$ & $20.00 \mathrm{~b}$ & $81.67 \mathrm{a}$ & $60.83 \mathrm{a}$ & $100.00 \mathrm{a}$ & $97.33 \mathrm{a}$ & $85.83 \mathrm{a}$ & $100.00 \mathrm{a}$ \\
\hline Glyphosate (7.05 l/ha) & $71.67 \mathrm{a}$ & $86.33 \mathrm{a}$ & $86.00 \mathrm{ab}$ & $22.33 \mathrm{~b}$ & $94.00 \mathrm{a}$ & $50.00 \mathrm{a}$ & $100.00 \mathrm{a}$ & $96.33 \mathrm{a}$ & $91.33 \mathrm{a}$ & $100.00 \mathrm{a}$ \\
\hline Glyphosate (9.40 l/ha) & $78.33 \mathrm{a}$ & $49.17 \mathrm{~b}$ & $100.00 \mathrm{a}$ & $25.00 \mathrm{~b}$ & $98.83 \mathrm{a}$ & $60.00 \mathrm{a}$ & $100.00 \mathrm{a}$ & $99.17 \mathrm{a}$ & $88.13 \mathrm{a}$ & $100.00 \mathrm{a}$ \\
\hline Paraquat $(2.35 \mathrm{l} / \mathrm{ha})$ & $5.83 \mathrm{~d}$ & $96.67 \mathrm{a}$ & $75.20 \mathrm{~b}$ & $22.50 \mathrm{~b}$ & $15.83 \mathrm{bc}$ & $32.50 \mathrm{ab}$ & $61.67 \mathrm{bc}$ & $26.67 \mathrm{~b}$ & $66.83 \mathrm{ab}$ & $91.83 \mathrm{ab}$ \\
\hline Dalapon (5.65 kg/ha) & $13.33 \mathrm{~cd}$ & $35.00 \mathrm{~b}$ & $28.67 \mathrm{c}$ & $0 \mathrm{~b}$ & $18.33 \mathrm{~b}$ & $2.50 \mathrm{~b}$ & $19.17 \mathrm{c}$ & $5.83 \mathrm{c}$ & $0.83 \mathrm{~b}$ & $80.50 \mathrm{~b}$ \\
\hline Check-Handweeded & $30.00 \mathrm{bc}$ & $38.33 \mathrm{~b}$ & $69.17 \mathrm{~b}$ & $0 \mathrm{~b}$ & $4.17 \mathrm{c}$ & $16.33 \mathrm{~b}$ & $86.67 \mathrm{ab}$ & $20.83 \mathrm{bc}$ & $0.83 \mathrm{~b}$ & $56.67 \mathrm{c}$ \\
\hline
\end{tabular}

${ }^{1}$ Means in columns followed by the same letters do not differ significantly at the 0.05 probability level. 
TABLE 2.-Frequency of herbicide aplication on a young coffee grove

\begin{tabular}{|c|c|c|c|c|c|c|c|c|c|c|c|}
\hline \multirow{3}{*}{ Herbicide } & \multicolumn{9}{|c|}{1979} & \multicolumn{2}{|c|}{1980} \\
\hline & \multirow{2}{*}{ Mrch 5} & \multirow{2}{*}{ April 30} & \multicolumn{2}{|c|}{ May } & \multirow{2}{*}{ June 1} & \multirow{2}{*}{ June 19} & \multirow{2}{*}{ Aug. 7} & \multirow{2}{*}{ Oct. 5} & \multirow{2}{*}{ Nov. 15} & \multirow{2}{*}{ Jan. 24} & \multirow{2}{*}{ Feb. 15} \\
\hline & & & 8 & 22 & & & & & & & \\
\hline Glyphosate (2.35 1/ha) & $\mathrm{X}$ & $\mathrm{X}$ & & & & $\mathrm{x}$ & $\mathrm{x}$ & & $\mathrm{X}$ & & $\mathrm{X}$ \\
\hline Glyphosate $(4.70 \mathrm{l} / \mathrm{ha})$ & $\mathrm{X}$ & $\mathrm{X}$ & & & & & $\mathrm{X}$ & & $\mathrm{X}$ & & $\mathrm{X}$ \\
\hline Glyphosate (7.05 l/ha) & $\mathrm{X}$ & $\mathrm{X}$ & & & & & $\mathrm{X}$ & & $\mathrm{X}$ & & $\mathrm{X}$ \\
\hline Glyphosate (9.40 I/ha) & $\mathrm{X}$ & & & $\mathrm{X}$ & & & $\mathrm{X}$ & & $\mathrm{X}$ & & $\mathrm{X}$ \\
\hline Paraquat $(2.35 \mathrm{l} / \mathrm{ha})$ & $\mathrm{X}$ & $\mathrm{X}$ & $\mathrm{X}$ & & & $\mathrm{X}$ & $\mathrm{X}$ & $\mathrm{X}$ & $\mathrm{x}$ & $\mathrm{X}$ & $\mathrm{X}$ \\
\hline Dalapon $(5.65 \mathrm{~kg} / \mathrm{ha})$ & $\mathrm{x}$ & $\mathrm{X}$ & & & & & $\mathrm{X}^{1}$ & $\mathrm{X}$ & $\mathrm{X}$ & & $\mathrm{X}$ \\
\hline Check-Handweeded & $\mathrm{X}$ & $\mathrm{X}$ & & & $\mathrm{x}$ & & $\mathrm{X}$ & $\mathrm{X}$ & $\mathrm{X}$ & & $\mathrm{x}$ \\
\hline
\end{tabular}

${ }^{1}$ Handweeded August 7, 1979 because of poor weed control. 
The following treatments were compared: glyphosate $(2.35,4.70,7.50$ and $9.40 \mathrm{l} / \mathrm{ha})$; paraquat $(2.35 \mathrm{l} / \mathrm{ha})$; dalapon $(5.65 \mathrm{~kg} / \mathrm{ha})$; and a control (clean cultivation by handweeding when needed). Treatment differentials were applied March 5, 1979, and subsequently as required by weed growth.

Monthly observations were made to determine the efficacy of each herbicide treatment on control of weeds and any detectable injury to the crop. The evaluation was done on a 0 to 100 scale basis, where 0 equals no control or high crop injury and 100 equals complete weed control with no crop toxicity. Coffee height was measured three times to determine the detrimental effect of the treatments on coffee growth. The check plots were handweeded as needed and the weeds weighed throughout the period in which the experiment was active.

TABLE 3.-Coffee height $(\mathrm{cm})$ and percent mortality as affected by the application of postemergence herbicides to recently transplanted coffee trees

\begin{tabular}{|c|c|c|c|c|}
\hline \multirow{2}{*}{ Herbicide } & \multicolumn{3}{|c|}{ Height $(\mathrm{cm})$} & \multirow{2}{*}{$\begin{array}{c}\text { Dead trees } \\
2 / 15 / 80\end{array}$} \\
\hline & $2 / 20 / 79$ & $5 / 25 / 79$ & $2 / 13 / 80$ & \\
\hline & & & & $\%$ \\
\hline Glyphosate (2.35 l/ha) & $59.21 \mathrm{a}^{1}$ & $67.39 \mathrm{ab}$ & 102.92 & 0 \\
\hline Glyphosate (4.70 I/ha) & $51.71 \mathrm{ab}$ & $64.74 \mathrm{ab}$ & 109.14 & 0 \\
\hline Glyphosate (7.05 l/ha) & $57.61 \mathrm{a}$ & $70.31 \mathrm{a}$ & 113.54 & 4 \\
\hline Glyphosate $(9.40 \mathrm{l} / \mathrm{ha})$ & $60.45 \mathrm{ab}$ & $76.91 \mathrm{ab}$ & 112.73 & 1 \\
\hline Paraquat (2.35 l/ha) & $54.00 \mathrm{ab}$ & $63.50 \mathrm{ab}$ & 96.34 & 2 \\
\hline Dalapon (5.65 kg/ha) & $54.13 \mathrm{ab}$ & $63.55 \mathrm{ab}$ & 89.99 & 4 \\
\hline Check-Handweeded & $54.76 \mathrm{~b}$ & $64.52 \mathrm{~b}$ & 93.83 & 10 \\
\hline
\end{tabular}

${ }^{1}$ See table 1.

The experimental site was predominantly infested with Panicum maximum, Brachiaria purpurascens (Raddi) Henr., Digitara sanguinalis, Paspalum conjugatum. Ipomoea tiliacea, Commelina diffusa, Solanum torvum, Solanum caribaeum, Cissus sicyoides, and Urena lobata when the experiment was started.

\section{RESULTS AND DISCUSSION}

Table 1 presents the percentage of weed control obtained. The information presented indicates that glyphosate at 4.70, 7.05, and $9.40 \mathrm{l} / \mathrm{ha}$ provided excellent (85 to 100\%) and very good control (70 to $84 \%$ ) when applied at $2.35 \mathrm{l} / \mathrm{ha}$. Glyphosate controlled the weeds more effectively than the other herbicides.

Ipomoea tiliacea was least susceptible to paraquat. Dalapon, as expected, did not provide good broadleaf weed control, but was very effective against the grasses Panicum maximum, Brachiaria purpurascens; and Digitaria sanguinalis. These data provide supporting evidence that dalapon should be used in rotation or mixed with another herbicide to keep coffee plantations free of weeds. 
Table 2 shows the frequency of treatment. It was necessary to make a second glyphosate application 56 days after the first in order to obtain complete weed control. When it was applied at $9.40 \mathrm{l} / \mathrm{ha}$, the second application was made 78 days later. The glyphosate effect when applied at $2.35 \mathrm{l} /$ ha lasted from 2 to 2.5 months; thus it was necessary to apply it six times in 1 year to obtain complete weed control, but at 4.70, 7.05, and $9.40 \mathrm{l} /$ ha its effect lasted around $31 / 2$ to 4 months. On the other hand, it was necessary to apply paraquat nine times in 12 months in order to keep weeds under control.

Table 3 shows data on coffee height as affected by the application of each herbicide. Glyphosate did not have any detrimental effect on the height of the coffee trees. However, the other two herbicides, paraquat

TABLE 4.-Time required (minutes per treatment) for controlling weeds, and their weight as affected by the frequency of application of glyphosate, paraquat, dalapon and handweeding ${ }^{1}$

\begin{tabular}{lcc}
\hline \multicolumn{1}{c}{ Herbicide } & Min./treatment & Weed weight \\
\hline Glyphosate $(2.35 \mathrm{l} / \mathrm{ha})$ & $160 \mathrm{a}^{2}$ & $0 \mathrm{a}$ \\
Glyphosate $(4.70 \mathrm{l} / \mathrm{ha})$ & $104 \mathrm{ab}$ & $0 \mathrm{a}$ \\
Glyphosate $(7.05 \mathrm{l} / \mathrm{ha})$ & $109 \mathrm{~b}$ & $0 \mathrm{a}$ \\
Glyphosate $(9.40 \mathrm{l} / \mathrm{ha})$ & $114 \mathrm{ab}$ & $0 \mathrm{a}$ \\
Paraquat $(2.35 \mathrm{l} / \mathrm{ha})$ & $246 \mathrm{~d}$ & $0 \mathrm{a}$ \\
Dalapon $(5.65 \mathrm{~kg} / \mathrm{ha})$ & $358 \mathrm{c}$ & $1762.5 \mathrm{~b}$ \\
Check Handweeded & $379 \mathrm{c}$ & $4740.0 \mathrm{c}$ \\
\hline
\end{tabular}

${ }^{1}$ Data are the total of 6 replicates.

${ }^{2}$ In each column: means followed by one or more letters in common do not differ significantly at $\mathrm{P}=0.01$, according to Duncan's multiple range test.

and dalapon, caused a slight coffee height reduction. This height reduction may be due to poorer weed control, thus more weed competition for nutrients and water.

Table 3 also shows the percentage of dead coffee trees. The highest mortality was recorded on the check plots; thus, the phytotoxicity of the herbicides under comparison was not the cause. This high mortality also suggests that weed competition (although the handweeding was done as frequently as needed on the control plots) is a limiting factor in establishing a coffee grove. Handweeding also caused mechanical injuries to the roots and stems, which could reduce tree growth and allow the entrance of pathogenic organisms.

Glyphosate, at the different rates tested, reduced the labor requirements needed to keep the plots free of weeds (table 4). Significant differences were observed when compared with the time needed to apply paraquat, dalapon, or to handweed the non-treated plots. The amount of weeds harvested per treatment also demonstrated the effectiveness of 
glyphosate and paraquat. Dalapon was only significantly superior to handweeding.

\section{RESUMEN}

Con el propósito de evaluar la eficacia de glifosato en plantaciones recién establecidas a pleno sol y su efecto sobre el desarrollo de los cafetos, se realizó un experimento en la Subestación de Adjuntas. El predio experimental está localizado en lat. $18^{\circ} 11^{\prime} \mathrm{N}$, long. $66^{\circ} 48^{\prime} \mathrm{O}$ a una altitud de $588 \mathrm{~m}$.

Arbolitos de café de la variedad Borbón sembrados en bolsas plásticas se transplantaron al campo en agosio de 1978. Siete tratamientos se aplicaron el 5 de marzo de 1979. Los tratamientos se repitieron seis veces en un diseño de parcelas pareadas en bloques incompletos. Las parcelas experimentales constaron de ocho arbustos de café. Los tratamientos evaluados fueron glifosato aplicado a razón de 2.35, 4.70, 7.05 y $9.40 \mathrm{I}$ ha; paraquat a $2.35 \mathrm{l} / \mathrm{ha}$, dalapon a $5.65 \mathrm{~kg} / \mathrm{ha}$ y el testigo (talado a machete), aplicados tantas veces como fuera necesario para mantener un buen control de los yerbajos.

Los datos presentados señalan que el glifosato es un herbicida muy eficaz en el control de yerbajos en el cafetal. Paraquat fue especialmente eficaz contra las gramíneas y controló muy bien los yerbajos de hoja ancha. Todos los tratamientos de glifosato controlaron aceptablemente los yerbajos, especialmente cuando se aplicó a razón de 4.70, 7.05 y 9.40 1/ha. Se corroboró que cuando se aplica Roundup a esas concentraciones las aspersiones se pueden reducir a 3 ó 4 por año, mientras que para mantener un buen control de los yerbajos con $2.35 \mathrm{l} / \mathrm{ha}$ de paraquat es necesario aplicarlo aproximadamente cada 45 días. La fitotoxicidad del glifosato en el cafeto es prácticamente nula si se asperja directamente sobre los yerbajos. No obstante, si el arbusto se moja inadvertidamente con la solución, puede causar un estancamiento temporero del crecimiento apical. Este efecto se disipa aproximadamente a los 2 meses, luego de lo cual el arbusto continúa creciendo normalmente.

\section{LITERATURE CITED}

1. Boneta-Garcia, E. G., 1980. Frequency of herbicide applications to coffee groves, J. Agric. Exp. Stn. Univ. P. R. 64 (3): 249-58.

2. Burril, L. C., Cárdenas, J., and Locatelli, E., 1977. Manual de campo para investigación en control de malezas, Publ. 22 A 77, International Plant Protection Center, Oregon State Univ., Corvallis.

3. Conjunto Tecnólogico para la producción de café, 1976. Esta. Exp. Agric. Univ. P. R. Publ. 104.

4. Eastin, E. F., 1972. Evaluation of summer applied herbicides for control of purple nutsedge in Brazos County in 1971, Texas Agric. Exp. Stn. Prog. Rep. 3016.

5. Liu, L. C., Rodriguez-García, J. and Semidey-Laracuente, N. 1981. Glyphosate for weed control in plantains, J. Agric. Univ. P. R. 65 (4): 317-25. 
HERBICIDES IN COFFEE GROVES: WEED CONTROL, GROWTH 269

6. Otto, N. E., 1970. Evaluation of soil-applied herbicides for vegetation control: A water resources tech. publ. U. S. Dep. Int. Water Resources Tech. Publ. Res. Rep. 22, Washington, D. C.

7. Páez, J. A., 1973. Efectivo Control de Gramalote con Aspersiones de Dowpon, Biokemia 20: $1-3$.

8. Vélez, I. and J. Van Overbeek, 1950. Plantas Indeseables en los Cultivos Tropicales, Editorial Universitaria, Rio Piedras, P. R.

9. Vicente-Chandler, J., 1977. Programa para una Agricultura Moderna en Puerto Rico, 1977-78 al 1980-81. Rep. Mimeo, San Juan, P. R.

10. —- Abruña, F., and Silva, S., 1959. A guide to intensive coffee culture, USDA Prod. Res. Rep. 31. 